\title{
FEMORAL COMPONENT WEAR IN RETRIEVED HIP PROSTHESES
}

\author{
A. KUSABA, Y. KUROKI \\ From Showa University Fujigaoka Hospital, Yokohama, Japan
}

We retrieved 159 femoral heads at revision surgery to determine changes in surface configuration. Macroscopic wear of the head was observed in three bipolar hip prostheses as a result of three-body wear. There was a considerable change in surface roughness in the internal articulation of bipolar hip prostheses. Roughness in alumina heads was almost the same as that in new cobalt-chromium heads. The annual linear wear rate of polyethylene cups with alumina heads was less than that of cups with cobalt-chromium alloy heads. Polyethylene wear was increased in the prostheses which had increased roughness of the head.

J Bone Joint Surg [Br] 1997;79-B:331-6.

Received 2 September 1996; Accepted after revision 23 December 1996

Wear is one of the most important factors which influence the long-term results of hip arthroplasty ${ }^{1-5}$ and occurs principally in the polyethylene cup. ${ }^{2-11}$ It also occurs in the femoral component the surface configuration of which affects the rate of polyethylene wear. ${ }^{9-12}$ There have been few reports about the wear of femoral components and our aim was to evaluate the in vivo changes in the surface configuration.

\section{MATERIALS AND METHODS}

We studied 149 head components retrieved from 128 patients ( 8 men and 120 women). Details of the implants, the diagnoses and revision rates are given in Table I. The removal procedure was performed with great care in order not to damage the prosthesis during revision surgery.

We used a roughness meter (SE 3300, Kosaka Co Ltd,

A. Kusaba, MD, Instructor

Department of Orthopaedic Surgery, Showa University Fujigaoka Hospital, 1-30 Fujigaoka, Aoba-Ku, Yokohama 227, Japan.

Y. Kuroki, MD, Director of the Hospital

Showa University Fujigaoka Rehabilitation Hospital, 2-1-1 Fujigaoka, Aoba-Ku, Yokohama 227, Japan.

Correspondence should be sent to Dr A. Kusaba at 824-9 Kamoshida-Cho, Aoba-Ku, Yokohama 227, Japan.

(C)1997 British Editorial Society of Bone and Joint Surgery 0301-620X/97/27217\$2.00
Tokyo, Japan) to measure the mean surface roughness (Ra: arithmetical mean value of arithmetical mean roughness) of the retrieved heads calculating the mean roughness $(\mu \mathrm{m})$ (Ra) as follows (Fig. 1):

where $\mathrm{L}$ is the length of the measured area $(1.25 \mathrm{~mm})$ and the cut-off value is $0.25 \mathrm{~mm}$. The wavelength corresponding to the the trace speed was $0.05 \mathrm{~mm} / \mathrm{s}$. The Ra value was taken as the mean of nine points measured in sagittal and coronal planes on the upper half of the head (Figs 2a and 2b; Table II).

The linear wear value of the cups was measured using Wroblewski's shadow-graph technique ${ }^{13}$ in the 105 hips in which the cups and heads were retrieved concurrently.

\section{RESULTS}

Macroscopic changes. Deformity of the head (Fig. 3) resulting from wear was observed in the internal articulation in three bipolar prostheses. The mean loss of volume was $2142 \mathrm{~mm}^{3}$ (1999 to 2328). The acetabula had been reamed at the primary surgery and acetabuloplasty had been performed using the resected femoral neck which had been fixed with alumina screws. The heads had migrated until they contacted the screws which were broken in two cases and worn in one. Circular scratches were observed on the

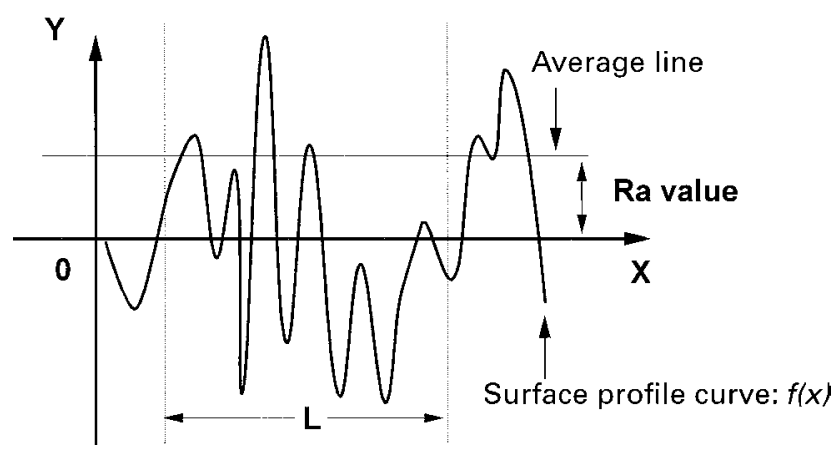

Fig. 1

Diagram to show measurement of the Ra value which is obtained by sampling the reference length in the direction of the mean line, taking the $\mathrm{X}$-axis as the direction of mean line and $\mathrm{Y}$-axis the direction of longitudinal magnification of the sampled part. The roughness curve is expressed as $\mathrm{y}=\mathrm{f}(\mathrm{x})$. 
Table I. Details of implants, fixation and revision in 149 hips

\begin{tabular}{|c|c|c|c|c|}
\hline & \multicolumn{4}{|l|}{ Type of implant* } \\
\hline & Müller & Weber-Stühmer & Kyocera & Bipolar (UHR, Bateman) \\
\hline Number of heads & 36 & 54 & 19 & 40 \\
\hline Head diameter in $\mathrm{mm}$ & 32 & 32 & 28 & 22 \\
\hline Head material & CoCr alloy & Alumina & Alumina & CoCr alloy \\
\hline Number of cups & 24 & 54 & 16 & 40 \\
\hline Cup material & UHMWPE $\dagger$ & UHMWPE & UHMWPE & UHMWPE \\
\hline Years in situ (range) & $9.0(4.7$ to 15.7$)$ & $8.5(1.5$ to 16.5$)$ & $6.6(0.6$ to 10.4$)$ & $5.1(0.6$ to 10.7$)$ \\
\hline $\begin{array}{l}\text { Fixation } \\
\text { Cup } \\
\text { Stem }\end{array}$ & $\begin{array}{l}\text { Cemented } \\
\text { Cemented }\end{array}$ & $\begin{array}{l}\text { Cemented } \\
\text { Cemented }\end{array}$ & $\begin{array}{l}\text { Cemented } \\
\text { Cemented }\end{array}$ & $\overline{-}$ \\
\hline $\begin{array}{l}\text { Diagnosis at primary replacemen } \\
\text { Dysplastic osteoarthritis } \\
\text { Others }\end{array}$ & $\begin{array}{r}36 \\
0\end{array}$ & $\begin{array}{r}50 \\
4\end{array}$ & $\begin{array}{r}19 \\
0\end{array}$ & $\begin{array}{r}33 \\
7\end{array}$ \\
\hline $\begin{array}{l}\text { Diagnosis at revision } \\
\text { Aseptic loosening } \\
\text { Others }\end{array}$ & $\begin{array}{r}35 \\
1\end{array}$ & $\begin{array}{r}50 \\
4\end{array}$ & $\begin{array}{r}18 \\
1\end{array}$ & $\begin{array}{r}33 \\
7\end{array}$ \\
\hline Age at revision in years (range) & $55.0(29$ to 55$)$ & $51.6(30$ to 73$)$ & 53.3 (39 to 64$)$ & 53.8 (36 to 78$)$ \\
\hline Mean follow-up in years & 16.9 & 13.1 & 11.7 & 6.5 \\
\hline Revision rate (\%) (number) & $49(39 / 80) \ddagger$ & $19(67 / 354) \ddagger$ & $20(19 / 99)$ & $13(40 / 301)$ \\
\hline
\end{tabular}

* Müller and Weber-Stühmer, Gebrüle and Sulzer AG, Winterthur, Switzerland; Kyocera, Kyocera Corporation, Kyoto, Japan; UHR, Osteonics, New Jersey; Bateman, 3M Company, Minnesota

$\dagger$ ultra-high-molecular-weight polyethylene

\$ prostheses which were damaged during the revision surgery were excluded from this study

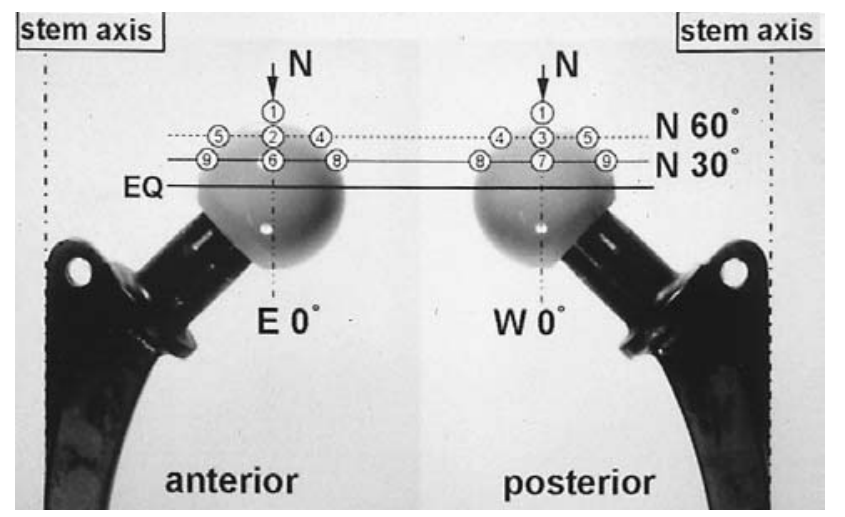

Measuring points of the retrieved head, see Table II. Figure $2 \mathrm{a}-$ Anterior and posterior view of the head (right hip). The stem axis line is parallel to the line through the north and south poles $(\mathrm{N}$, north pole; EQ, equator; $\mathrm{N}$ $30^{\circ}$, north 30 degrees; $\mathrm{N} 60^{\circ}$, north 60 degrees; E $0^{\circ}$; east 0 degrees; and $\mathrm{W} 0^{\circ}$, west 0 degrees). Figure $2 \mathrm{~b}$ - Diagram of right and left heads from above showing the measuring points.

Fig. 2a

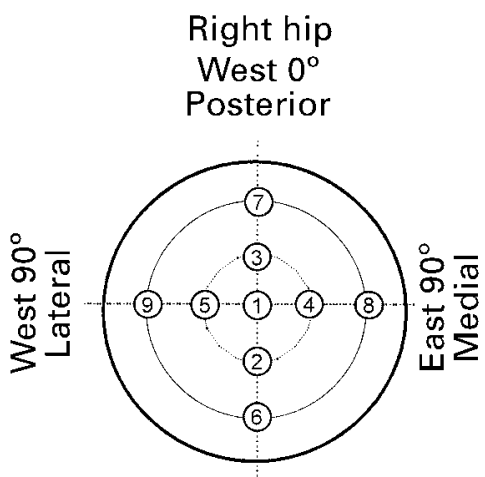

East $0^{\circ}$

Anterior

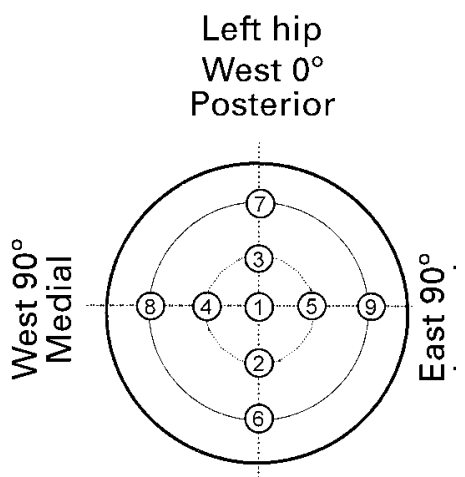

East $0^{\circ}$

Anterior

Latitude $60^{\circ}$

Latitude $30^{\circ}$

Fig. 2b 
Table II. Measuring points on the head of the prosthesis. The head is considered as a terrestrial globe; the line passing through the north and south poles is parallel to the axis of the stem (see Fig. 2)

\begin{tabular}{llllll}
\hline \multirow{2}{*}{ Point number } & \multicolumn{2}{l}{ Right hip } & & \multicolumn{2}{l}{ Left hip } \\
\cline { 2 - 3 } \cline { 5 - 6 } 1 (top) & Latitude & Longitude & & Latitude & Longitude \\
\hline 2 (anterior) & North 60 & East 0 & & North 60 & West 0 \\
3 (posterior) & North 60 & West 0 & & North 60 & West 90 \\
4 (medial) & North 60 & East 90 & & North 60 & East 90 \\
5 (lateral) & North 60 & West 90 & North 60 & West 90 \\
6 (anterior) & North 30 & East 0 & & North 30 & West 0 \\
7 (posterior) & North 30 & West 0 & & North 30 & East 0 \\
8 (medial) & North 30 & East 90 & North 30 & West 90 \\
9 (lateral) & North 30 & West 90 & North 30 & East 90 \\
\hline
\end{tabular}

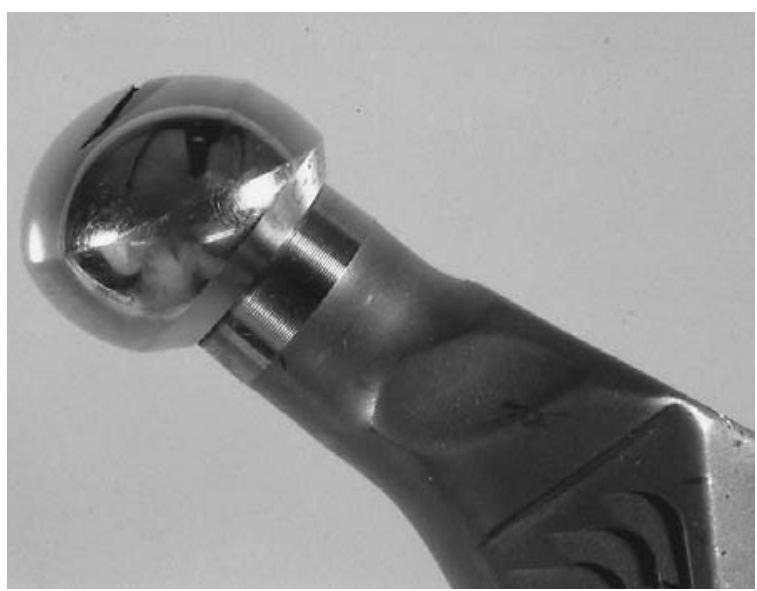

Fig. 3

Severely deformed inner head of a bipolar hip prosthesis, showing its rugby-ball shape. metal shell of the outer heads and numerous black alumina particles on the articulation surface of the polyethylene which had abraded the inner head. A mass of black tissue was seen during revision and all three patients had a high serum concentration of chromium (13.5 to $46.2 \mu \mathrm{g} / \mathrm{dl}$ ) and nickel $(0.9$ to $1.1 \mu \mathrm{g} / \mathrm{dl})$. Such changes were not seen in the heads of fixed-cup prostheses. Since they were caused by obvious three-body wear they were excluded from the measurement of the surface roughness of the head and polyethylene wear.

Microscopic changes. The mean Ra values of the other retrieved heads are shown in Figure 4. The roughness of the alumina heads was less than that of new cobalt-chromium alloy heads (Figs 4 to 6). The maximum change was observed in the area near the pole, with statistically significant differences between the ranges of $\mathrm{Ra}$ values in $32 \mathrm{~mm}$ cobalt-chromium alloy heads, $32 \mathrm{~mm}$ alumina heads, and $28 \mathrm{~mm}$ alumina heads $(\mathrm{p}<0.01)$ (Fig. 7).

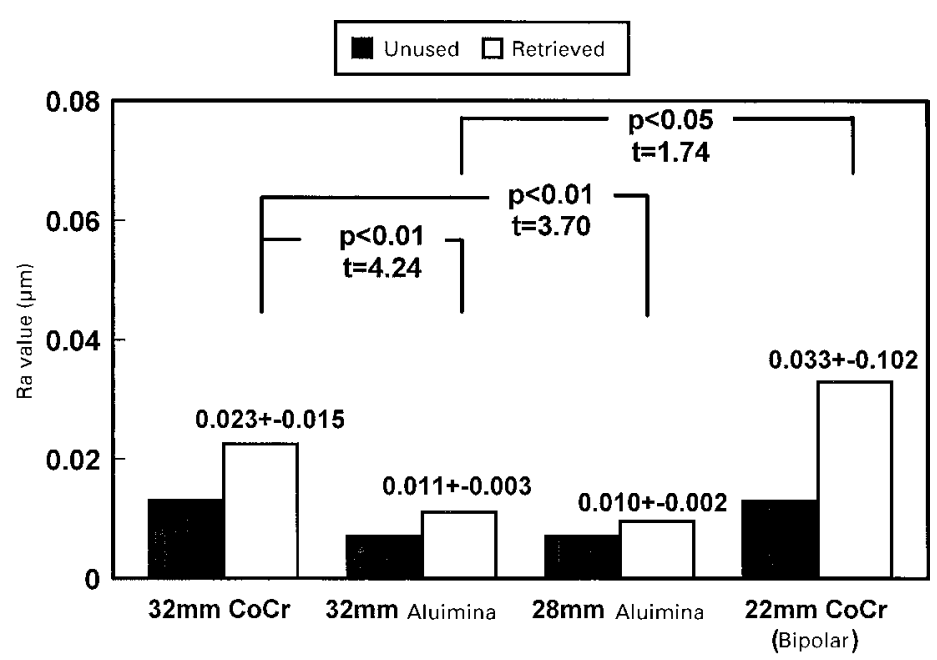

Fig. 4

The mean $( \pm \mathrm{SD})$ Ra values of the retrieved heads.

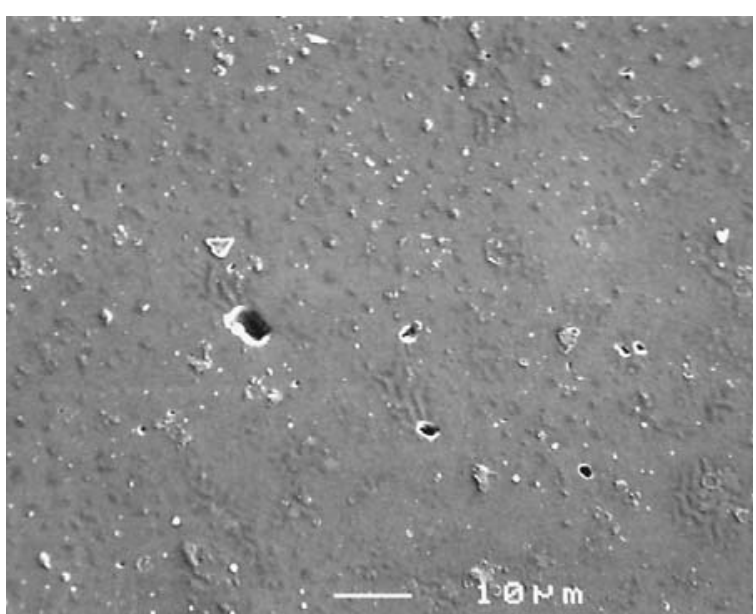

Fig. 5

Scanning electron micrograph of a retrieved $32 \mathrm{~mm}$ alumina head after 15.7 years in situ $(\times 420)$. 


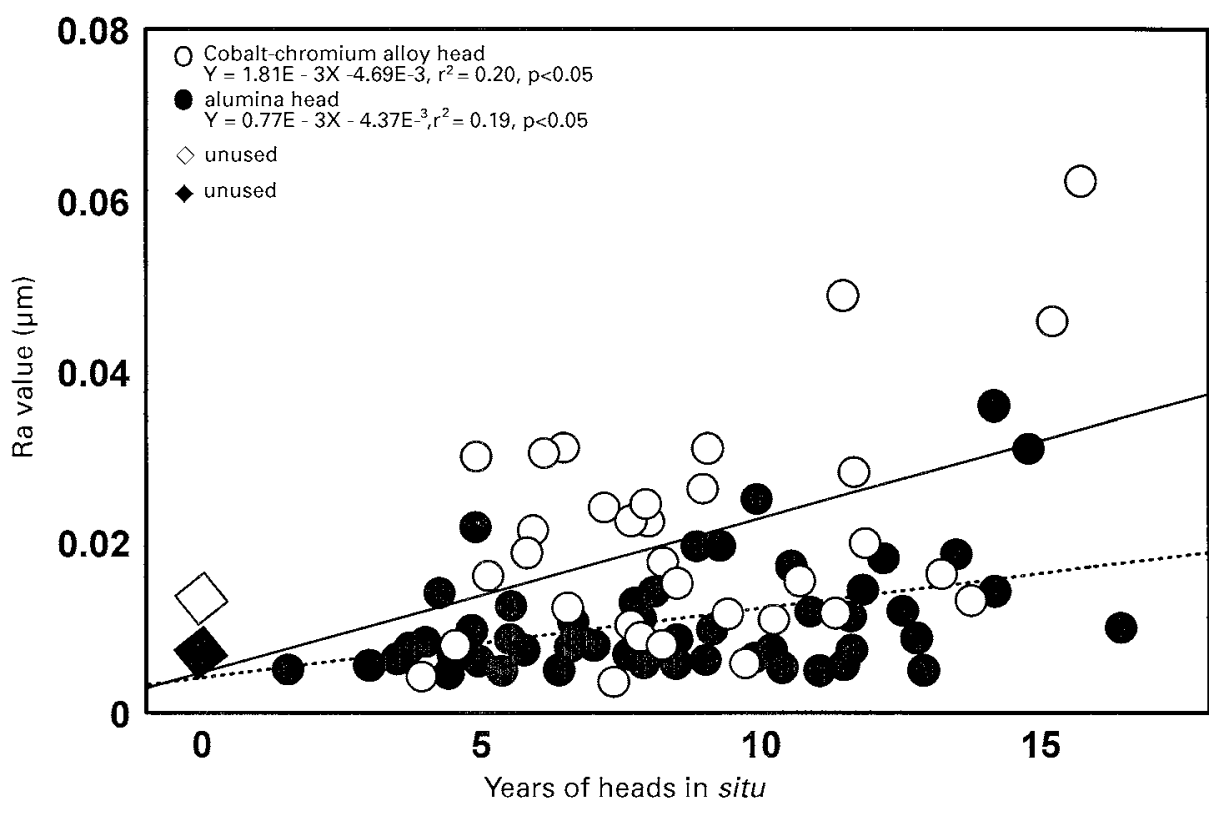

Fig. 6

The relationship of roughness to the years in situ in alumina and cobalt-chromium heads.

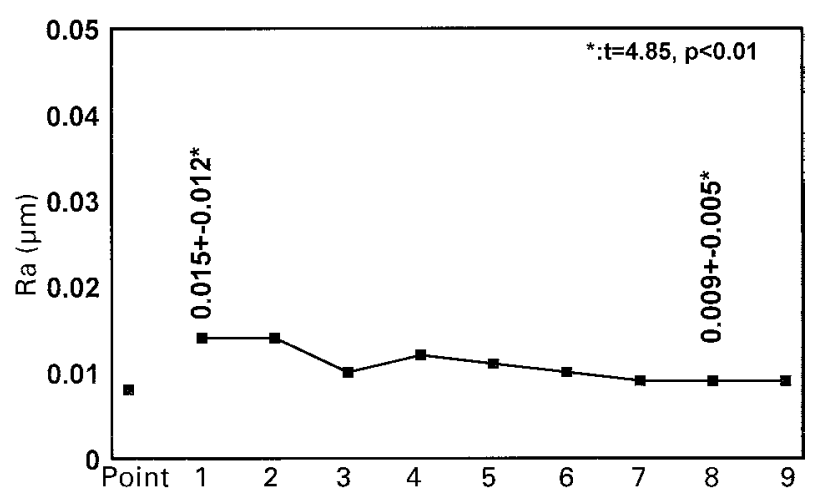

Fig. 7a

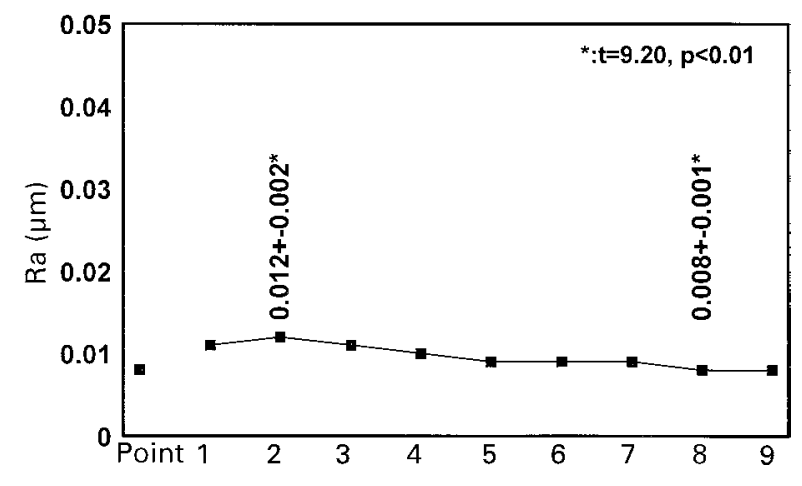

Fig. 7c

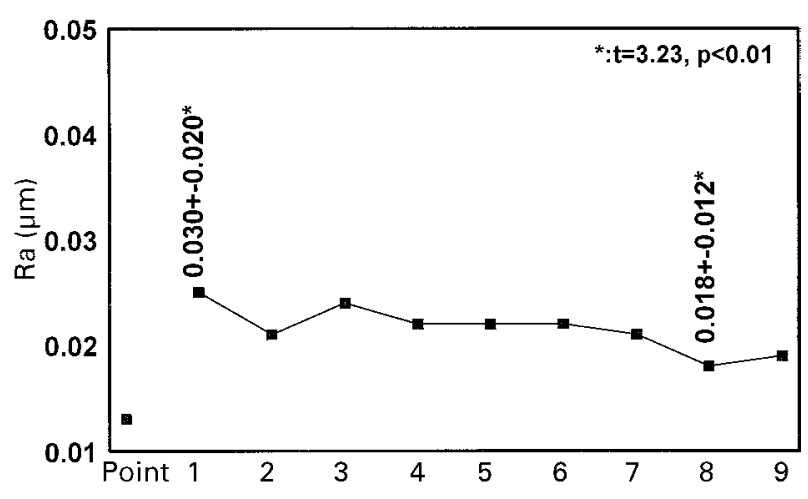

Fig. $7 b$

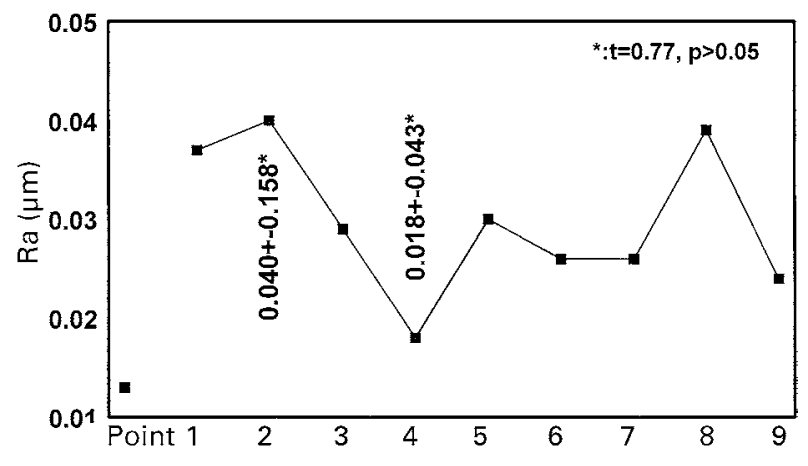

Fig. 7d

Local roughness of a retrieved $32 \mathrm{~mm}$ alumina head (a), a $32 \mathrm{~mm}$ cobalt-chromium alloy head (b), a $28 \mathrm{~mm}$ alumina head (c) and a $22 \mathrm{~mm}$ cobalt-chromium alloy inner head of a bipolar prosthesis $(\mathrm{d})$. 


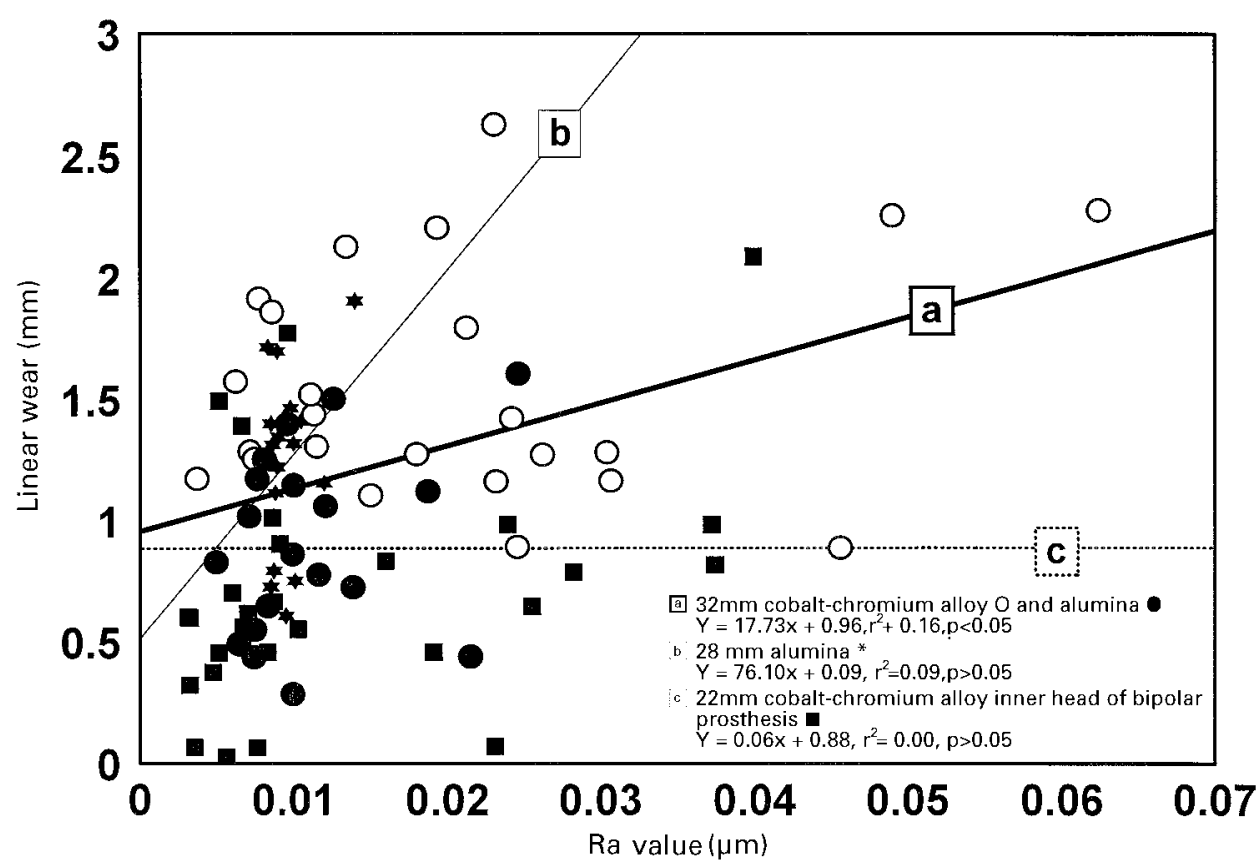

Fig. 8

The relationship of head roughness (Ra) to linear polyethylene wear.

Table III. The mean $( \pm \mathrm{sD})$ wear rate of retrieved cups (mm/year)

\begin{tabular}{lllll}
\hline \multicolumn{4}{l}{ Type of implant } & \\
\cline { 2 - 5 } & Müller & Weber-Stühmer & Kyocera & Bipolar \\
\hline Number of cups & 24 & 35 & 16 & 37 \\
Wear rate & $0.21 \pm 0.09 *$ & $0.13 \pm 0.05$ & $0.15 \pm 0.03$ & $0.21 \pm 0.17$ \\
\hline$*$ t-study: $\mathrm{t}=3.85, \mathrm{p}<0.05$ & & &
\end{tabular}

Polyethylene wear. Table III shows the annual linear wear rate which was smaller in $32 \mathrm{~mm}$ alumina heads than in $32 \mathrm{~mm}$ cobalt-chromium alloy heads ( $\mathrm{t}$-study: $\mathrm{t}=-3.85$, $\mathrm{p}<0.05)$. Polyethylene wear was directly related to the roughness of the head (Fig. 8).

\section{DISCUSSION}

The roughness of the internal articulation of bipolar hip prostheses was high compared with that of other prostheses and was associated with severe polyethylene wear. Radiological measurements of polyethylene cups in situ have shown that wear rates of bipolar hip prostheses are higher than those with fixed cups. ${ }^{14,15}$

The polyethylene wear rate of fixed cups in our study is higher than those which have previously been reported. ${ }^{16-21}$ It is clear that wear is worse in failed prostheses and is one of the most important factors in the cause of failure. ${ }^{21-23}$ Most of the patients were young and had dysplastic hips treated by arthroplasty; their high level of activity may also have contributed to early failure. ${ }^{22}$

The wear rate of polyethylene cups with $32 \mathrm{~mm}$ alumina heads was less than that of the cups with cobalt-chrome heads of similar size. Our radiological analyses have also shown that wear in situ of alumina/polyethylene prostheses is less than that of cobalt-chrome alloy/polyethylene prostheses. $^{24}$

We wish to thank Dr T. Tateishi of the National Mechanical Engineering Laboratory, Dr Y. Shirasaki of the National Mechanical Engineering Laboratory and Dr Morio Tsuge of Sumitomo Bakelite Techno-research for their valuable advice.

No benefits in any form have been received or will be received from a commercial party related directly or indirectly to the subject of this article.

\section{REFERENCES}

1. Charnley J. Wear of hip sockets. In: Low friction arthroplasty. New York: Springer-Verlag, 1979:320-31.

2. Griffith MJ, Seidenstein MK, Williams D, Charnley J. Socket wear in Charnley low friction arthroplasty of the hip. Clin Orthop 1978; 137:37-47.

3. Hernandez JR, Keating EM, Faris PM, Meding JB, Ritter MA. Polyethylene wear in uncemented acetabular components. $J$ Bone Joint Surg [Br] 1994;76-B:263-6.

4. Tooms RE, Harkess JW. Arthroplasty. In: Crenshaw AH, ed. Campbell's operative orthopaedics. Vol 3. 8th ed. St. Louis: Mosby Inc, 1992:371-87.

5. Wroblewski BM. 15-21 year results of the Charnley low friction arthroplasty. Clin Orthop 1986;211:30-5. 
6. Black J. Materials retrieval and analysis. In: Black J, ed. Orthopaedic biomaterials in research and practice. New York: Churchill Livingstone, 1988:319-31.

7. Dowling JM, Atkinson JR, Dowson D, Charnley J. The characteristics of acetabular cups worn in the human body. J Bone Joint Surg [Br] 1978;60-B:375-82.

8. Kabo JM, Gebhard JS, Loren G, Amstutz H. In vivo wear of polyethylene acetabular components. J Bone Joint Surg [Br] 1993; 75-B:254-8.

9. McKellop HA, Sarmiento A, Schwinn CP, Ebramzadeh E. In vivo wear of titanium-alloy hip prostheses. J Bone Joint Surg [Am] 1990; 72-A:512-7.

10. Plitz W, Walter A. Tribological aspects of metal/polymer couplings. In: Buchhorn GH, Willert HG, eds. Technical principles, design and safety of joint implants. Seattle, etc: Hogrefe and Huber Publishers, 1994:82-9.

11. Streicher RM. Tribology of artificial joints. In: Morscher EW, ed. Endoprosthetics. Berlin, etc: Springer-Verlag, 1995:34-48.

12. Kumar P, Oka M, Ikeuchi K, et al. Low wear rate of UHMWPE against zirconia ceramic (Y-PSZ) in comparison to alumina ceramic and SUS 316L alloy. J Biomed Mater Res 1991;25:813-28.

13. Wroblewski BM. Direction and rate of socket wear in Charnley lowfriction arthroplasty. J Bone Joint Surg [Br] 1985;67-B:757-61.

14. Kusaba A. In vivo wear of bipolar endoprosthesis. Nippon Seikeigeka Gakkai Zasshi 1995;69:411-25.

15. Kusaba A, Kuroki Y, Kondo S. Radiologic wear measurement of bipolar hip prosthesis. Orthopaedic Transactions 1996;20:in press.
16. Dumbleton JH, Black J. Some long-term complications. In: Ling RSM, ed. Complications of total hip replacement. Edinburgh, etc: Churchill Livingstone, 1984:212-30.

17. Livermore J, Ilstrup D, Morrey B. Effect of femoral head size on wear of the polyethylene acetabular component. J Bone Joint Surg [Am] 1990;72-A:518-28.

18. Semlitsch M, Lehmann M, Weber H, Doerre E, Willert H-G. New prospects for a prolonged functional life-span of artificial hip joints by using the material combination polyethylene/aluminium oxide ceramic metal. J Biomed Mater Res 1977;11:537-52.

19. Weber BG. Total hip replacement: rotating versus fixed and metal versus ceramic heads. In: Salvati EA, ed. The hip. St Louis: Mosby. 1981:264-75.

20. Bono JV, Sanford L, Toussaint JT. Severe polyethylene wear in total hip arthroplasty. J Arthroplasty 1994;9:119-25.

21. Schmalzried TP, Guttmann D, Grecula M, Amstutz HC. The relationship between the design, position, and articular wear of acetabular components inserted without cement and the development of pelvic osteolysis. J Bone Joint Surg [Am] 1994;76-A:677-88.

22. Feller JA, Kay PR, Hodgkinson JP, Wroblewski BM. Activity and socket wear in the Charnley low-friction arthroplasty. J Arthroplasty 1994;9:341-5.

23. Zichner LP, Willert H-G. Comparison of alumina-polyethylene and metal-polyethylene in clinical trials. Clin Orthop 1992;282:86-94.

24. Kusaba A, Kuroki Y, Kawauchi K, et al. Clinical results of ceramic hip prosthesis. Orthopaedic Ceramic Implant 1994;14:59-63. 